\title{
EVALUATION OF THE IN VITRO ANTIMICROBIAL ACTIVITY OF CRUDE EXTRACTS OF THREE MICONIA SPECIES
}

\author{
Andréa Carla Celotto; Daniela Zaupa Nazario; Marcela de Almeida Spessoto; Carlos Henrique Gomes Martins; \\ Wilson Roberto Cunha*
}

Núcleo de Pesquisa em Ciências Exatas e Tecnológicas, Universidade de Franca, Franca, SP, Brasil.

Received: March 05, 2003; Returned to Authors for corrections: July 25, 2003; Approved: September 21, 2003

\section{SHORT COMMUNICATION}

\begin{abstract}
The antimicrobial activity of nine crude extracts of three Miconia species (M. albicans, M. rubiginosa and M. stenostachya) was tested against eleven selected microorganisms: Staphylococcus aureus, Staphylococcus saprophyticus, Proteus mirabilis, Escherichia coli, Enterococcus faecalis, Shigella flexneri, Klebsiella pneumoniae, Salmonella sp, Pseudomonas aeruginosa, Streptococcus agalactiae and Candida albicans. The results of the test showed that three extracts had some antimicrobial activity by well diffusion method. The ethanol extracts of Miconia albicans and Miconia rubiginosa were the most active.
\end{abstract}

Key words: antimicrobial activity, Miconia, Melastomataceae.

In many parts of Brazil there is a tradition in the use of herbal medicine for treatment of infectious diseases $(11,12)$.

On account that pathogenic microorganisms can develop resistance against antibiotics, attention has been paid to extracts and biologically active compounds isolated from plant species (5). Antimicrobials of plant origin are efficient in the treatment of infectious diseases mitigating simultaneously many of the side effects that are often associated with synthetic antimicrobials (8).

The current study was carried out to determine the in vitro antimicrobial activity of crude extracts of Miconia species. Miconia is a genus with approximately 1,000 species (10), which belongs to Melastomataceae family. Studies on Miconia species are scarce. Miconia extracts and their isolated compounds have demonstrated biological activities such as antimalarial, antitumoral, analgesic and antifungal action $(1,2,6,9)$.

Miconia species (M. albicans, M. rubiginosa and $M$. stenostachya) were collected along Franca-Claraval highway, São Paulo, Brazil and identified by Dr. Angela Borges Martins,
Instituto de Biologia, UNICAMP, Brazil. Vouchers specimens have been deposited in the Herbarium of the same Institute. The aerial parts of the plants were dried at $40^{\circ} \mathrm{C}$, powdered and extracted at room temperature with hexane, methylene chloride and ethanol, respectively.

Four Gram-positive bacteria (Staphylococcus aureus ATCC 25923, Staphylococcus saprophyticus ATCC 35552, Enterococcus faecalis ATCC 19943 and Streptococcus agalactiae), six Gram-negative bacteria (Proteus mirabilis NCTC 8309, Escherichia coli ATCC 14942, Shigella flexneri ATCC 12022, Klebsiella pneumoniae ATCC 11296, Salmonella sp ITAL SM SN 004 and Pseudomonas aeruginosa ATCC 27853) and one yeast specie (Candida albicans) were studied. $S$. agalactiae and $C$. albicans were isolated from patients of the Laboratório de Análises Clínicas (Universidade de Franca).

Antimicrobial activity of the extracts was determined by well diffusion method on plates with a double layer of Brain Heart Infusion agar (7). The inocula were subcultured in Brain Heart Infusion broth. After complete solidification, wells were

*Corresponding author. Mailing address: Núcleo de Pesquisa em Ciências Exatas e Tecnológicas da Universidade de Franca. Av. Dr. Armando Salles de Oliveira, 201, Parque Universitário. 14404-600, Franca, SP, Brasil. Fax: (+5516) 3711-8886. E-mail: wrcunha@unifran.br 
prepared by removing the agar with plastic straws. Prior to the antimicrobial testing each organic extract was dried and the residue was dissolved in DMSO at concentration of $300 \mathrm{mg} /$ $\mathrm{mL}$. The wells were then filled with $20 \mu \mathrm{L}$ of the extracts solution. One well was filled with DMSO as negative control. Then, the plates were preincubated for $2 \mathrm{~h}$ at room temperature and then incubated for $24 \mathrm{~h}$ at $35^{\circ} \mathrm{C}$. Antimicrobial activity was determined by measuring the inhibition halos around the wells in millimeters. All samples were tested in triplicate. A total of nine extracts of three Miconia species were investigated and the ethanol extracts exhibited an antimicrobial effect against some of the eleven tested microorganisms (Table 1).

Results showed that ethanol extracts of M. albicans and M. rubiginosa were the most active. The ethanol extract of $M$. stenostachya was active only against $C$. albicans, E. coli, P. aeruginosa, $P$. mirabilis, Salmonella sp and E. faecalis were resistant for all extracts. A previous study on these species of Miconia has revealed the presence of triterpene acids $(3,4,13)$. The antimicrobial activity observed for the ethanol extracts can be explained by the presence of a mixture of substances, including triterpene acids, in these extracts with antimicrobial properties, indicating that $M$. albicans and M. rubiginosa are a valuable source for the discovery of new antimicrobial products.

Table 1. Antimicrobial activity of ethanol extracts of Miconia species $^{\mathrm{a}}$.

\begin{tabular}{lccc}
\hline Microorganisms & $\begin{array}{c}\text { M. albicans } \\
(300 \mathrm{mg} / \mathrm{mL})\end{array}$ & $\begin{array}{c}\text { M. rubiginosa } \\
(300 \mathrm{mg} / \mathrm{mL})\end{array}$ & $\begin{array}{c}\text { M. stenostachya } \\
(300 \mathrm{mg} / \mathrm{mL})\end{array}$ \\
\hline S. aureus & $16.7 \pm 1.53$ & $19.0 \pm 1.73$ & - \\
S. saprophyticus & $13.7 \pm 0.58$ & $14.0 \pm 0.58$ & - \\
S. agalactiae & $11.0 \pm 0.00$ & $13.7 \pm 0.58$ & - \\
E. faecalis & - & - & - \\
P. aeruginosa & - & - & - \\
P. mirabillis & - & - & - \\
E. coli & - & - & - \\
Salmonella sp. & - & - & - \\
S. flexneri & $11.7 \pm 1.15$ & $13.0 \pm 1.00$ & - \\
K. pneumoniae & $15.3 \pm 0.58$ & $15.7 \pm 1.15$ & - \\
C. albicans & $19.7 \pm 0.58$ & $20.7 \pm 1.15$ & $10.7 \pm 0.58$ \\
\hline
\end{tabular}

${ }^{a}$ Values are inhibition halos $(\mathrm{mm})$ and an average of triplicate (Mean \pm S.D.); - , no inhibition.

\section{ACKNOWLEDGEMENTS}

This study was supported by FAPESP (Proc. 00/03911-4). We wish to thank Alba Regina Barbosa and Maria Inês Junqueira Garcia Teixeira for helping with plant collection.

\section{RESUMO}

\section{Avaliação da atividade antimicrobiana in vitro de extratos brutos de três espécies de Miconia}

A atividade antimicrobiana de nove extratos de três espécies de Miconia (M. albicans, M. rubiginosa e M. stenostachya) foi avaliada frente a onze microrganismos: Staphylococcus aureus, Staphylococcus saprophyticus, Proteus mirabilis, Escherichia coli, Enterococcus faecalis, Shigella flexneri, Klebsiella pneumoniae, Salmonella sp, Pseudomonas aeruginosa, Streptococcus agalactiae e Candida albicans. Três destes extratos apresentaram atividade antimicrobiana pelo método de difusão de poço. Os extratos etanólicos de Miconia albicans e Miconia rubiginosa foram os mais ativos.

Palavras-chave: atividade antimicrobiana, Miconia, Melastomataceae.

\section{REFERENCES}

1. Andrade e Silva, M.L.; Cunha, W.R.; Pedro, C.; Garcia, P.A.; Martins, C. Evaluation of the analgesic activity of an ethanol extract of Miconia fallax. Boll. Chim. Farmac., 141:158-160, 2002.

2. Antoun, M.K.; Gerena, L.; Milhous, W.K. Screening of the flora of Porto Rico for potential antimalarial bioactives. Intern. J. Pharmacog., 4:255-258, 1993.

3. Chan, W.R.; Shepard, V.; Medford, K.; Tinto, N.F.; Reynolds, W.F.; McLean, S. Triterpenes of Miconia stenostachya. J. Nat. Prod., 55:963-966, 1992.

4. Cunha, W.R.; Martins, C.; Ferreira, D.S.; Crotti, A.E.M.; Lopes, N.P.; Albuquerque, S. In vitro trypanocidal activity of triterpenes from Miconia species. Planta Med., 69:468-470, 2003.

5. Essawi, T.; Srour, M. Screening of some palestinian medicinal plants for antibacterial activity. J. Ethnopharmacol., 70:343-349, 2000.

6. Hasrat, J.A.; De Backer, J.P.; Valquelin, G.; Vlietinck, A.J. Medicinal plants in suriname: screening of plants extracts for receptobinding activity. Phytomedicine, 4:56-65, 1997.

7. Hawcroft, D.; Hector, T.; Rowell, F. Quantitative Bioassay. Wiley, New York, 1988.

8. Iwu, M.W.; Duncan, A.R.; Okunji, C.O. New antimicrobials of plant origin. In: Janick, J. (ed.) Perspectives on New Crops and New Uses. ASHS Press, Alexandria, VA, 1999, p.457-462.

9. Li, X.-C.; Jacob, M.R.; Pasco, D.S.; Elsohly, H.N.; Ninrod, A.C.; Walker, L.A.; Clark, A.M. Phenolic compounds from Miconia myriantha inhibiting Candida Aspartic proteases. J. Nat. Prod., 64:1282-1285, 2001.

10. Martins, A.B.; Semir, J.; Goldenberg, R.; Martins, E. O gênero Miconia Ruiz \& Pav. No estado de São Paulo. Acta Bot. Bras., 10:267-316, 1996.

11. Septimio, L.R. Fitoterapia baseada em ervas medicinais do cerrado, SIPE. Ministério da Agricultura, Brasília, 1994.

12. Souza Brito, A.R.M.; Souza Brito, A.A. Forty years of Brazilian Medicinal Plant Research. J. Ethnopharmacol., 39:53-67, 1993.

13. Spessoto, M.A.; Ferreira, D.S.; Crotti, A.E.M.; Silva, M.L.A.; Cunha, W.R. Evaluation of the analgesic activity of extracts of Miconia rubiginosa (Melastomataceae). Phytomedicine, 10:606-609, 2003. 